\title{
An Investigation into Management Response to Negative Online Reviews in Hotel Operations
}

\section{Hassan Sherif}

Department of Mass Communication, Tourism \& Fine Arts, University of Bahrain, Kingdom of Bahrain

\section{Abstract}

The advent of webz and the interactivity it allowed net surfers to communicate freely with the purpose of exchanging ideas and opinions regarding the products they have purchased has given rise to a new marketing tool identified in the literature as consumer-generated content. As travel and hospitality are amongst the highest purchased services on the World Wide Web, a multitude of sites are

Corresponding Author: Hassan Sherif hsharif@uob.edu.bh

Received: 18 September 2018 Accepted: 10 October 2018 Published: 15 October 2018

Publishing services provided by Knowledge E

(c) Hassan Sherif. This article is distributed under the terms of the Creative Commons

Attribution License, which permits unrestricted use and redistribution provided that the original author and source are credited.

Selection and Peer-review under the responsibility of the Sustainability and Resilience Conference Committee.
G OPEN ACCESS currently made available to travelers to express either their satisfaction or voice their complaints on hotel properties that they have stayed at for business or pleasure. In providing informational queues, these online reviews are strongly affecting traveler's pre-purchase decisions and their attitudes toward hotel choice. One factor that is considered of great effect on this decision-making process is identified as management response to reviews; regardless of their positive or negative nature. The purpose of this research is to provide an investigation into management's behavior in responding to negative online reviews and the manner in which this type of feedback is handled in a way to build customer trust as well as a venue to service recovery.

Keywords: Customer-generated Content, Online Reviews, Travel, Hospitality, Management Response, Bahrain

\section{Introduction}

The interactivity characteristic of webz has allowed travelers to increasingly resort to elicit online information about travel destinations, airlines, hotels and restaurants as well as other myriad services they plan to purchase on their travel adventure. This bi-directional nature of sharing electronic word of mouth (eWOM) has changed the marketing field of hospitality and opened up new frontiers not present a few years ago. Nowadays, travelers are increasingly depending on online reviews (OLRs) to make their accommodation purchase decisions (UNWTO, 2014) where more than $50 \%$ have chosen a hotel after consulting online review sites (ReviewPro, 2014). These OLRs 
were identified as the most influential information source for travel planning (Kwok et al., 2017) affecting traveler consumer behavior (Browning et al., 2013), company's financial performance (You et al., 2015), hotel room sales (Phillips et al., 2017), occupancy rate (Viglia and Buhalis, 2016), quality perceptions (Torres et al., 2014), booking intentions (Casalo et al., 2015), customer satisfaction (Gu and Ye, 2014), market share (Duverger, 2013) as well as employee stress (Bradley et al., 2015). Furthermore, in their attempt to assess the influence of OLRs, some researchers (Li et al., 2015; Banerjee and Chua, 2016; Liu and Park 2015; Radojevic et al., 2015) used web crawlers in order to quantitatively determine how third party platforms use algorithms to rate hotels as to service quality, value for money and customer satisfaction. Others (Kusumasondjaja et al., 2012; Rose and Blodgett, 2016), created hypothetical settings where customers were asked to imagine planning a trip and then provided with several reviews in order to measure the effect these may have on their travel choice behavior. Witnessing such a growing need of information on part of potential travelers as well as increasing concern to hotel operators, the main aim of this research is to investigate the degree of attention management has assigned to monitor online consumer generated content and how this process is handled on its part. In doing so, and in order to avoid management biased response (Niu and Fan, 2018), the research does not directly approach management but observes its consequent response behavior toward their properties' OLRs posted on third party platforms. The 'guru' "TripAdvisor" was chosen as the ground of investigation as it is considered by many to be the leading platform for travelers to voice their appreciation and/or dismay (Filieri et al., 2015; Casalo et al., 2015).

\section{Literature Review}

The growth of 'eMediaries' (Buhalis and Licata 2002) is attributed in large to answering increasing travelers demand for unbiased information. Some of these sites have become important obligatory points of passage providing authoritative opinion over a particular domain (Jeacle and Carter, 2011). Posted OLRs, also known in the literature as consumer generated content, is considered a form of eWOM, which Hennig-Thurau et al., (2004) refer to as "any positive or negative statement made by potential, actual or former consumers about a product or company, which is made available to a multitude of people and institutions via the Internet". The impact of OLRs is considered more salient when the product in question is of a service nature (Kwok and Yu, 2016) 
allowing no trial prior to purchase and consumption thus rendering it difficult to judge beforehand.

In the area of travel and hospitality, consumers write OLRs as a post purchase behavioral engagement to indicate their level of satisfaction and inform others about their hotel experience. Many reviews are posted in real time at the moment of, or directly after, service delivery while the experience is still fresh in mind, not tarnished by the passage of time. These reviews may incorporate stories, photos, videos and "moments of truth" that these customers have encountered during their stay. This represents a challenge as reviews provide both positive and negative evaluations, remaining on sites for a considerable time period (Browning et al., 2013), and augmented by the fact that such sites are considered to be trustworthy (Ladhari and Michaud, 2015) not only in the area of travel but in many areas of endeavor as well. O'Mahony and Smyth (2010) explain that while the interfaces of these platforms may look different, they present the same three common features of: evaluation (of the product), reputation (of reviewers) and social (among reviewers, managers and users). Ip et al., (2012) report that almost $33 \%$ of respondents to their survey had resorted to travel websites for travel planning and that many of these have shared their travel experience online. Those percentages have increased as online travel sites gained more popularity where Xie et al., (2014), report that $53 \%$ of travelers would not commit to a hotel reservation until they check its OLRs, and that $77 \%$ stated that they would usually or always refer to such reviews before their final choice of accommodation. What compounds the importance of OLRs lies in the research findings (Cantallops and Salvi, 2014; Karakaya and Barnes, 2010) that revealed that these are perceived as more trustworthy than official destination websites.

With regard to valence, OLRs that are in favor of hotel experience were found to increase hotel bookings (Torres et al., 2015), and market share (Duverger, 2013), while unfavorable comments adversely affected sales and business performance (Sparks and Browling, 2011). Nevertheless, Park and Nicklau (2015) found that people perceive reviews of extreme ratings (positive or negative) as more useful and enjoyable than those with moderate ratings. Similarly, Lee et al., (2009) report that negative reviews are more useful and persuasive than either neutral or positive opinions with regard to their credibility and impact on attitude formation. Such view was expressed earlier by Chiou and Cheng (2003), who, on the basis that negative reviews are usually less in number, attributed their effect to the phenomenon of 'scarcity' which commands more attention and motivates consumers in resolving uncertainty. 
Allied to the scarcity phenomenon, a considerable amount of research within the field of marketing suggests that because of the negativity effect (Tsang and Prendergast, 2009), negative reviews are stronger and more influential than positive reviews (Casalo et al., 2015) and that their impact is more pronounced for hotel services when compared to tangible goods (Christodoulides et al., 2012), hence influencing the decision making of potential guests to a greater extent.

\section{Response to OLRs}

Existing research has predominantly adopted a marketing perspective and extensively analyzed the impact of OLRs on consumer behavior and decisions, however, how management responds to such reviews didn't receive as much attention (Magno et al., 2017; Abramova et al., 2018).

Furthermore, although the literature on service recovery indicate that companies that respond effectively to customer complaints benefit from increased customer loyalty and greater profitability (Ogut and Tas, 2012); that the influence of management response is a factor that should never be underrated (Levy et al., 2013); that such responses should be considered the first point of call for hotel managers (Xie et al., 2016); not much research has addressed the issue of assessing the effectiveness of hotel marketers' response to OLRs (Rose and Blodgett, 2016). As a matter of fact, hoteliers have been criticized in not making enough investment in online reputation management (ReviewPro, 2014) despite the academic guidance that research has presented.

Lee et al., (2012) explain that non-action strategies may allow negative reviews to stand unchallenged thereby potentially damaging reputation and image, resulting in poor satisfaction ratings and low loyalty (Sparks and Bradely, 2017) and putting a company in a disadvantageous position leading to customers loss. Lee and Carnage (2014) and Sparks and Bradely (2016) concur on the premise that the provision of a response will reduce the likelihood of readers drawing their own negative erroneous inferences. Other studies (Min et al., 2015; Pelsmacker et al., 2018) also confirmed the importance of responding to uploaded opinions and urged hotels to treat OLRs as a new addition to their marketing communication mix.

In addition, it is reported that management can increase the perceived helpfulness of OLRs with strategic responses (Liu and Park, 2015). Kwok et al., (2015), provided evidence that managers' timely addressed response helps consumers identify the 
reviews that deem helpful and thus reduces cognitive load in finding useful information. Levy et al (2013) highly recommend managers to provide immediate and authentic response to OLRs because effective responses were found to be positively related to customers' loyalty and perceived as more informative and reliable than those left unattended. Similarly, Rancourt (2013) expresses that the reaction to customer reviews can be more telling than the review itself and may turn the tide to a favorable outcome.

Similarly, Xie et al., (2014) stated that responses by management to OLRs proves that management is listening, expressing appreciation and reinforcing the extent of care and human connection which helps building up goodwill. Gu and Ye (2014) added that addressing service failure prevents switching behavior and influences perception of justice and fairness, and improve customers' morale and attitude towards the company (Sahin et al., 2017). Likewise, Pantelidis (2010), described several examples where an intervention from the company moderated and improved negative reviews and led to 'follow-up commentaries that are priceless'.

Furthermore, Zehrer et al., (2011) found that negative postings were not necessarily bad if followed by a positive counter reaction, while Barsky and Frame (2009) explained that buffering complaints is a service recovery strategy that may turn tables and strengthen trust. Anderson, (2012) found that managerial response to negative reviews is more profitable than answering positive ones, while Sparks et al., (2016) reported that provision of response enhanced inferences potential customers draw regarding business's trustworthiness and extent of care.

In response to this growing need, leading hotel review websites such as TripAdvisor and yelp feature dedicated management accounts where hotel managers can interact with reviewers by responding to their feedback. On both of these sites, managers may post one response to every comment thus providing a mean for engagement and interaction with customers who have been described by Litvin et al., (2008) as "the opinion leaders in travel choice", "contributors to negative image projection" (Vermuelen and Seegers, 2009) and who represent a price increasing barrier to hotel operations (Ogut and Tas 2012).

\section{Methodology}

It has been argued that the ability of operators to respond to online reviews is understudied in the little research focusing on this behavior (Lui et al., 2018; Abramova et al., 2015). Moreover, recent studies (Chevalier et al., 2016) have indicated that managerial 
response to negative reviews is more critical than answering positive ones and represent a manifestation of the operator's capability to utilize a system that projects a service oriented strategy. As such, and towards achieving the research objectives, this study aims to explore answers to the following pertaining questions:

1. What is the degree of attention that hotel management has directed toward their online response behavior.

2. Is the hotel's competitive stance affected by the weight of negative reviews in comparison to total online customer-generated content, in both categories of TripAdvisor's ranking and the conventional star rating system.

3. How does the tendency of managerial response to online reviews affect the hotel's competitive performance in terms of its attention, acknowledgement, speed and type of response to online reviewers.

The study collected data from TripAdvisor as it is the largest and most popular online review channel for travel accommodation (Filieri et al., 2015; Casalo et al., 2015). Data collection concentrated on the responses given by the top 99 hotels ranked by the online channel in the Kingdom of Bahrain. It need be noted that TripAdvisor demonstrates two different ranking systems. The first of these lists hotels according to 'travelers' ranking' where reviewers' feedback is the determining factor influencing the ranking procedure, while the second classification ranks the properties according to their 'best value'. The first category was chosen for the purpose of this study. To our knowledge, this is the first attempt to investigate such an aspect in the growing hospitality industry of Bahrain. In this respect, registered reviewers on TripAdvisor rate hotel operations along a five point Likert type scale of excellent, very good, average, terrible and poor. As reported in other studies (Ho, 2017), a close reading of the reviews showed that only those belonging to the average, poor and terrible contained negative comments. In order to contain the research to negative feedback, this study limited its investigation to only the poor and terrible ratings, as average 'sitting on the fence' has shown to be of mixed content. The data on the top 99 hotels subject to the study were collected according to TripAdvisor's "travelers' ranking". These hotels were subdivided according to the rank they occupied into a three tier grouping of top, mid and low with each tier or group comprising 33 hotels. For comparison reasons, and in order to test for existent correlations, the analysis would, in certain cases resort to the most commonly used star rating system. All ninety nine hotels were listed on the Bahraini Tourism and Exhibition authority which is the main government body regulating the travel and hospitality businesses in the Kingdom of Bahrain. It need be noted that the 
analysis only takes into consideration those reviews that were in English. As these constitute $89 \%$ of total reviews, one may not look upon this as a shortcoming but a minor limitation of the research.

\section{Analysis of Results}

Table 1 summarizes the frequencies of the hotels under study, showing that the top tier hotels accounted for the largest number of reviews (16824) averaging 509 reviews per hotel followed by the mid (avg=80) and low tiers (avg=16). The table also shows the same variables distributed according to the star rating of the subject hotels.

TABLE 1: Frequencies.

\begin{tabular}{|c|c|c|c|c|c|c|c|c|}
\hline TripAdvisor's & No. of & Total & English & \multicolumn{2}{|c|}{ Negative Reviews } & \multicolumn{2}{|c|}{ Answered Reviews } & Helpful \\
\hline Ranking & Hotels & Reviews & Reviews & No. & $\%$ & No. & $\%$ & Reviews \\
\hline TOP & 33 & 16824 & 15005 & 777 & $5 \%$ & 601 & $77 \%$ & 859 \\
\hline MID & 33 & 2664 & 2331 & 419 & $18 \%$ & 162 & $39 \%$ & 1301 \\
\hline LOW & 33 & 531 & 449 & 168 & $37 \%$ & 9 & $5 \%$ & 1438 \\
\hline Total & 99 & 20019 & 17785 & 1364 & $8 \%$ & $\underline{772}$ & $57 \%$ & $\underline{3598}$ \\
\hline Stars & No. of & Total & English & \multicolumn{2}{|c|}{ Negative Reviews } & \multicolumn{2}{|c|}{ Answered Reviews } & Helpful \\
\hline Rating & Hotels & Reviews & Reviews & No & $\%$ & No & $\%$ & Reviews \\
\hline 5 & 16 & 11170 & 9890 & 539 & $5 \%$ & 418 & $78 \%$ & 392 \\
\hline 4 & 54 & 8057 & 7207 & 685 & $10 \%$ & 341 & $50 \%$ & 1957 \\
\hline 3 & 29 & 792 & 688 & 140 & $20 \%$ & 13 & $9 \%$ & 1249 \\
\hline Total & 99 & 20019 & 17785 & 1364 & $8 \%$ & 772 & $57 \%$ & 3598 \\
\hline
\end{tabular}

The aggregate results shown in table 1 shed light onto a primary question this research has presented. The first of these is represented in the relationship between the number of reviews and the position a hotel may occupy on TripAdvisor's ranking. Whether one considers the total number of reviews $(P C=.602$, sig=.000) or those that were posted in English $(P C=.593, \mathrm{sig}=.000)$, there were significant correlations signifying that the higher the number of reviews, the higher was the rank the hotel has occupied. Top tiered hotels accounted for the highest percentage of total reviews (84\%) followed by mid (13.3\%) and low tiers (2.6\%) respectively. This staggering difference may justify the fact that some hotel properties are increasingly being concerned with enhancing the number of reviews for their businesses, sometimes to the extent of solicitation (Gossling, 2016; Magno et al., 2017). 


\section{TripAdvisor's Ranking vs Star Classification}

At the outset, the analysis aimed to determine whether a correlation exist between the star rating of the subject hotels as bequeathed upon them by the Bahraini Tourism Authority and the rank assigned to them by TripAdvisor which the site bases on the score given to these properties by its registered reviewers. A significant negative correlation between hotels' star rating and its rank on the list $(-.686$, sig.000) indicates that TripAdvisor's' ranking does not wholly parallel the star rating system and that its ranking is not rigidly commensurate with the hierarchal star classification. That is to say that, regardless of the star categorization of any particular hotel, it is the guests' post experiential perception which determines how high the hotel is ranked on TripAdvisor. Table 2 shows a cross tabulation of the distribution of the hotels alongside their star ranking as well as their TripAdvisor's' position. It is noticeable that, for example, four star and three star properties were present in all three tiers of TripAdvisor's' ranks while five star properties had a concentration in the top rank with only minor representation elsewhere.

TABle 2: Hotel Star Rating * Hotel TripAdvisor's Ranking.

\begin{tabular}{|c|c|c|c|c|c|}
\hline & & \multicolumn{3}{|c|}{ Rank } & \multirow[t]{2}{*}{ Total } \\
\hline & & Top & Mid & Low & \\
\hline \multirow[t]{3}{*}{ Stars } & Three & 2 & 5 & 22 & 29 \\
\hline & Four & 16 & 27 & 11 & 54 \\
\hline & Five & 15 & 1 & 0 & 16 \\
\hline \multicolumn{2}{|l|}{ Total } & 33 & 33 & 33 & 99 \\
\hline \multicolumn{5}{|c|}{$($ chi $s q=57.8, d f=4, s i g=.000)$} & \\
\hline
\end{tabular}

\section{Valence of Negative Reviews}

In computing number and percentages of negative reviews voicing customers' dissatisfaction, the top ranked tier had the lowest of these at 5\% of total English reviews followed by $18 \%$ and $37 \%$ for mid and low tiers respectively. If the number and percentages of negative reviews signifies the level of customer satisfaction, then the correlation ( $P C=.691$, sig. $=.000)$ between the hotel rank and its percentage of negative reviews sustains TripAdvisor's' classification denoting that the lower the number of negative comments posted on a hotel, the higher it would rank on the travelers' site. The moderate coefficient, however, may be attributed to the fact that it is the valence of reviews which ultimately determines the hotel ranking in order to account for 'the 
good, the bad and the ugly' feedback by registered reviewers. Similar results were congruent when results showed that there is a significant relationship $(-.541, \operatorname{sig}=.000)$ between the number of negative reviews and the star rating of the hotels where the higher the star classification the lower was the number of dissatisfied customers airing their distress. A paired sample correlation shown in table 3 implies that there exist significant differences between both star classification and TripAdvisor's ranking and the number of negative reviews posted, yet the difference in the strength of the correlation sustains TripAdvisor's less dependence on the star rating classification in compiling its ranking mechanism and its reliance on customers' post purchase behavior in determining the outcome.

TABle 3: Percentage of Negative Reviews * Rank \& Star Rating.

\begin{tabular}{|l|l|l|c|c|c|c|}
\hline Pair 1 & $\begin{array}{c}\text { Rank \& Negative } \\
\text { Responses \% }\end{array}$ & 99 & .812 & .000 & 15.743 & 98 \\
\hline Pair 2 & $\begin{array}{c}\text { Stars \& Negative } \\
\text { Responses \% }\end{array}$ & 99 & -.541 & .000 & 44.028 & 98 \\
\hline
\end{tabular}

\section{Response to Negative Reviews}

As discussed in the literature review, service recovery may be achieved through answering guests' complaints (Sparks et al., 2016). Towards analyzing this end, results indicated that a significant correlation ( $P C=.908, \operatorname{sig}=.000$ ) existed between the number of negative reviews and those to which management has acknowledged and answered. This supports the trending strategy of many hotel companies in dedicating their efforts into monitoring and managing online reviews whether posted on their sites or on third party platforms. Nevertheless, there was a significant difference between the hotels TripAdvisor's rank and their tendency towards the attention and effort given to respond to guests' complaints ( $P C=-.808, \operatorname{sig}=.000)$ thus indicating that the higher the rank, the higher the reactive response of management to guests' voiced dismay.

Within this context, attention must be drawn to the lower ranked tier were $37 \%$ of its reviews were rated as either "poor" or "terrible". This implies a very low degree of meeting guest satisfaction which does not only place these properties at a disadvantaged rank on the travelers' site but which may affect potential travelers' perception of the subject hotels while flipping through the pages of the respectful site. Such 
detrimental placing is compounded by the results which revealed that only a mere $5 \%$ of these negative reviews were responded to by the subjects' management.

In order to determine which of the ranks was more responsive to negative reviews, a cross tabulation showed a significant relation (Chi sq=81.2, sig=.000) between hotel rank and tendency to respond where the top ranked hotels responded to $77 \%$ of their negative comments followed by the mid group that responded to less than half ( $39 \%)$. A mere $5 \%$ was the feeble attempts by the third classification. This strong difference in proactive behavior was sustained and depicted in table 4 where differences between the three tiers were present.

TABle 4: Response to Negative Reviews * Hotel TripAdvisor's Rank.

\begin{tabular}{|l|c|c|c|c|c|}
\hline & $\begin{array}{c}\text { Sum of } \\
\text { Squares }\end{array}$ & $\mathrm{df}$ & $\begin{array}{c}\text { Mean } \\
\text { Square }\end{array}$ & $\mathrm{F}$ & Sig. \\
\hline Between Groups & 11261.657 & 2 & 5630.828 & 8.262 & .000 \\
\hline Within Groups & 65423.697 & 96 & 681.497 & & \\
\hline Total & 76685.354 & 98 & & \\
\hline
\end{tabular}

In order to gain more understanding of the underlying differences in response behavior, running correlation between the number of responses to negative interviews using the 'stars' classification rather than TripAdvisor's' ranking, a significant correlation ( $P C=.630, s i g=.000)$ indicated that the higher the star rating, the higher the attention management has given to its response behavior. The existence of this different behavior towards providing answers to negative customer complaints was supported by results shown in table 5 . In this respect, cross tabulating the results (chi $s q=50.7, d f=8, s i g=.000)$ showed the highest responses (78\%) were attributed to the five star hotel properties followed by four and three stars respectively $(50 \%, 9 \%)$. As such, one may determine that properties falling into the five star classification have exhibited more adherence to policies regarding customer relationship management where the customers' opinions matter even after these customers have checked out. Attention need be drawn to the fact that, generally, star rating of hotel properties is based on the tangible characteristics and features of their physical evidence rather than on their level of customer orientation. However, strategies and policies regarding customer care and, in particular, attending to customer comments, should not solely lend themselves to higher star classification as results have indicated. 
TABle 5: Response to Negative Reviews * Hotel Star Rating.

\begin{tabular}{|l|c|c|c|c|c|}
\hline & $\begin{array}{c}\text { Sum of } \\
\text { Squares }\end{array}$ & $\mathrm{df}$ & $\begin{array}{c}\text { Mean } \\
\text { Square }\end{array}$ & $\mathrm{F}$ & Sig. \\
\hline $\begin{array}{l}\text { Between Groups } \\
\text { Within Groups Total }\end{array}$ & 7059.389 & 2 & 3529.695 & 43.152 & .000 \\
\hline & $\begin{array}{l}7852.571 \\
14911.960\end{array}$ & 96 & 81.798 & & \\
\hline
\end{tabular}

\section{Helpfulness of Negative Online Reviews}

This critical decline in management response may afflict harm on a hotel's online reputation, especially as results have revealed that, in total, 3598 TripAdvisor's' visitors have marked these negative comments as being helpful. This may lead us to believe that, in support of earlier literature (Phillips et al., 2017; Torres et al., 2015), there is no reason to doubt that these negative reviews have exerted a degree of influence on the site visitor' choice of accommodation. Running correlation between both variables, a moderate significant relationship ( $P C=.441, \operatorname{sig}=.000)$ was found between negative reviews posted on TripAdvisor and the number of helpful 'thumbs up' votes these reviews have gathered. However, in order to investigate whether there existed a difference between how helpful these reviews were to different hotel rankings, results showed a significant correlation ( $P C=.728, \operatorname{sig}=.000$ ) between how helpful these reviews were and the ranking of the hotel; indicating that, to a degree, reviews on the lower tier hotels gained more helpful votes than their higher counterparts. Interestingly, when review helpfulness was correlated to the 'star' rating of the hotels, correlation showed a significant difference $(P C=-.597, \operatorname{sig}=000)$ indicating that a higher star classification attracted a lower number of helpful votes per review. Results depicted in table 6 reflect how negative reviews have been found helpful to site visitors in terms of both TripAdvisor's' ranking as well as to the hotels' star classification.

TABLE 6: Helpfulness of Negative Reviews.

\begin{tabular}{|c|c|c|c|c|c|c|}
\hline & & $\begin{array}{l}\text { Sum of } \\
\text { Squares }\end{array}$ & $\mathrm{df}$ & $\begin{array}{l}\text { Mean } \\
\text { Square }\end{array}$ & $\mathrm{F}$ & Sig. \\
\hline \multirow[t]{3}{*}{ Rank } & Between Groups & 46.967 & 31 & 1.515 & $5 \cdot 333$ & .000 \\
\hline & Within Groups & 19.033 & 67 & .284 & & \\
\hline & Total & 66.000 & 98 & & & \\
\hline \multirow[t]{3}{*}{ Stars } & Between Groups & 23.386 & 31 & .754 & 2.539 & .001 \\
\hline & Within Groups & 19.907 & 67 & .297 & & \\
\hline & Total & 43.293 & 98 & & & \\
\hline
\end{tabular}


Finding a certain interest in these differences, a cross tabulation (chi sq=100.4, $d f=62$, sig=.002) have shown that on average, each negative comment on a top tier hotel picked up 1.1 helpful votes while the average multiplied to 3.1 helpful votes for their mid-tier counterparts and rose much further to 8.5 for the hotels falling into the lowest tier. A proposed justification to this phenomenon may rest in the fact that as many of the hotels falling into the top ranked tier by TripAdvisor are members of international chains as opposed to independent properties, one may argue that these properties enjoy a well-established image in the readers' minds, and that selective distortion might have come into play. Nevertheless, the number of site visitors' who have flagged the negative reviews $(n=1364)$ as being helpful $(n=3,598)$ sustains the growing importance of eWOM (Ladhari and Michaud, 2015) in shaping consumer behavior in the hospitality industry.

\section{Conclusion and Managerial Implications}

This study is the first to investigate hotel guests' online reviews for hospitality companies operating in the Kingdom of Bahrain. It is a timely response to the fast growing popularity of travel related information sharing platforms and travelers' increasing reliance on information posted by their peers in an effort to sustain their travel decisions regarding choice of hotel accommodation.

The study uses data from actual consumer reviews as opposed to methods of experimentation. While the latter can provide good understanding in approximating online behavior, they do not capture real behavior of hotel management responses to voiced complaints. As such, the analyzed behavior based data enhances the empirical strength of this research findings.

Findings reveal that hotel operations operating within the same sector and in the same geographic location may behave differently and incongruently in approaching and monitoring their reaction to consumer generated content. Toward this end, the sample hotels have taken different approaches in addressing online reviews. Given this disparity, more research is needed to draw the attention and guide hospitality operators to the ever increasing impact online reviews may have on their guest satisfaction, brand loyalty and financial performance.

The importance of such activities stem from the fact that as complaints and responses are publicly available, readers of online reviews can form a similar perception of a hotel's customer orientation strategies without physically interacting with employees thus vicariously testing the service beforehand. Hence, by encouraging 
response behavior to online reviews, hoteliers have the chance of offsetting the demonstrably damaging effects of negative reviews and enhance their score through diluting any excessive weight these reviews may result in.

Building upon this study, future research can focus on developing sampling rules based upon heuristics such as review length and reviewer characteristics that can be used to establish research validity in social media analytics in more efficient ways. Future research can also explore the effect of management response on reviewers' perception and their attitude and behavioral reactions with regard to service recovery and consideration of repatronage after responses being posted. Others aspects worth investigation could tackle issues such as speed of response to negative online reviews and the articulation of the response style.

Finally, eWOM is expected to continue to grow due to constant advancement in technology-driven communication channels. There is a growing belief that this concept is becoming more persuasive than other marketing instruments. As such, it is heeded that hoteliers seeking better overall success in their marketing endeavors to identify ways in which they can influence it to their advantage.

\section{References}

[1] Abramova, O., Shavanova, T., Fuhrer, A., Krasnova, H., \& Buxmann, P. (2015). Understanding the sharing Economy: The role of response to negative reviews in the peer-to-peer accommodation sharing network. European Conference on Information Systems (ECIS). At Münster, Germany, Volume 2015 Paper 1.

[2] Anderson, C. (2012). The impact of social media on lodging performance. Center for Hospitality Research Reports, 12 (15).

[3] Banerjee, S., Chua, A.Y.K., (2016). In search of patterns among travelers' hotel ratings in TripAdvisor. Tourism Monagement. V. 53 125-131.

[4] Barsky, J. \& Frame, C. (2009). Handling online reviews - best practices, available at: www.marketmetrix.com/en/default.aspx?s_research_HandlingOnlineReviews (accessed 13 January 2018).

[5] Blodgett, J. \& Anderson, R. (2000). A Bayesian Network Model of the Consumer Complaint Process, Journal of Service Research, V. 2 (4) 321-338.

[6] Bradley, G., Sparks, B. \& Weber, K. (2015). The stress of anonymous online reviews: a conceptual model and research agenda, International Journal of Contemporary Hospitality Management, V. 27 (5) pp. 739-755. 
[7] Browning, V., So, K. \& Sparks, B. (2013). The Influence of Online Reviews on Consumers' Attributions of Service Quality and Control for Service Standards in Hotels, Journal of Travel \& Tourism Marketing, V. 30 (1-2) 23-40.

[8] Buhalis, D., \& Licata, M. (2002). The future eTourism intermediaries, Tourism Management, V. 23 (3) 207-220.

[9] Cantallops, A. \& Salvi, F. (2014). New consumer behavior: a review of research on eWOM and hotels, International Journal of Hospitality Management, V. 36 (1) pp. 41-51.

[10] Casalo, L., Flavian, C. \& Guinaliu, M. (2007). The influence of satisfaction, perceived reputation and trust on a consumer's commitment to a website, Journal of Marketing Communications, V. 13 No. 1, pp. 1-17.

[11] Casalo, L., Flavian, C., Guinaliu, M. \& Ekinci, Y. (2015). Do online hotel rating schemes influence booking behaviors? International Journal of Hospitality Management, V. 49, pp. 28-36.

[12] Chan, N. \& Guillet, B. (2011). Investigation of social media marketing: how does the hotel industry in Hong Kong perform in marketing on social media websites? Journal of Travel and Tourism Marketing, V. 28 (4) Pp. 345-368.

[13] Chen, Y., Yong, L., \& Zhang, J. (2012). When do third-party product reviews affect firm value and what can firms do? The case of media critics and professional movie reviews. Journal of Marketing, V. 76 (2). 116-134.

[14] Chevalier, J. A., Dover, Y., \& Mayzlin, D. (2016). Channels of Impact: User reviews when quality is dynamic and managers respond. Available at: SSRN: https://ssrn. com/abstract $=2766873$.

[15] Chiou, J. \& Cheng, C. (2003). Should a company have message boards on its web sites?, Journal of Interactive Marketing, V. 17 No. 3, pp. 50-61.

[16] Christodoulides, G., Michaelidou, G., \& Argyriou, E. (2012). Cross-national differences in e-WOM influence. European Journal of Marketing 46 (11/12): 1689-707.

[17] Cui, G., Lui, H. \& Guo, X. (2012). The effect of online consumer reviews on new product sales, International Journal of Electronic Commerce, V. 17 No. 1, pp. 39-58.

[18] Duverger, P. (2013). Curvilinear effects of user-generated content on hotels' market share: a dynamic panel-data analysis, Journal of Travel Research, V. 52 (4) pp. 465478.

[19] Filieri, R., \& Mcleay, F. (2014). E-WOM and accommodation: An analysis of the factors that influence travelers' adoption of information from online reviews. Journal of Travel Research, 53 (1). 44-57. 
[20] Filieri, R., Alguezaui, S., \& McLeay, F. (2015). Why do travelers trust TripAdvisor? Antecedents of trust towards consumer-generated media and its influence on recommendation adoption and word of mouth. Tourism Management, 51, 174-185.

[21] Gretzel, U., \& Yoo, K., (2008). Use and impact of online travel reviews. In: O'Connor, P., Hopken, W., \& Gretzel, U. (Eds.). Information and Communication Technologies in Tourism, V. 2 Wien/New York, pp. 35-46.

[22] Gossling S, Hall CM \& Andersson AC (2016). The manager's dilemma: a conceptualization of online review manipulation strategies. Current Issues in Tourism. Epub ahead of print 12 January 2018. DOI: 10.1080/13683500.2015.1127337.

[23] Gu, B. \& Ye, Q. (2014). First step in social media: measuring the influence of online management responses on customer satisfaction, Production and Operations Management, V. 23 (4), pp. 570-582.

[24] Hennig-Thurau, T., Gwinner, K., Walsh, G., \& Gremler, D. (2004). Electronic word of mouth via consumer opinion platforms: what motivates consumers to articulate themselves on the Internet? Journal of Interactive Marketing, 18(1). 38-52.

[25] Ip, C., Lee, H. \& Law, R. (2012). Profiling the users of travel websites for planning and online experience sharing, Journal of Hospitality \& Tourism Research, V. 36 (3) pp. $418-426$.

[26] Jeacle, I. \& Carter, C. (2011). In TripAdvisor we trust: rankings, calculative regimes and abstract systems, Accounting, Organizations and Society, V. 36 (4/5), pp. 293-309.

[27] Jimenez, F. \& Mendoza, N. (2013). Too popular to ignore: The influence of online reviews on purchase intentions of search and experience products. Journal of Interactive Marketing, 27, 226-235.

[28] Jones, S. (1966). Some determinants of interpersonal evaluating behavior, Journal of Personality and Social Psychology, V. 3 No. 4, pp. 397-403.

[29] Karakaya, F., \& Barnes, N. (2010). Impact of online reviews of customer care experience on brand or company selection. Journal of Consumer Marketing 27 (5): 447-57.

[30] Kim, E., Mattila, A., \& Baloglu, S. (2011). Effects of gender and expertise on consumers' motivation to read online hotel reviews. Cornell Hospitality Quarterly, $52,399-406$.

[31] Kim, W., Lim, H. \& Brymer, R. (2015). The effectiveness of managing social media on hotel performance, International Journal of Hospitality Management, V. 44, pp. 165-171. 
[32] Kusumasondjaja, S., Shanka, T. \& Marchegiani, C. (2012). Credibility of online reviews and initial trust: The roles of reviewer's identity and review valence, Journal of Vacation Marketing, V. 18(3) 185-195.

[33] Kwok, L. \& Yu, B. (2016). Taxonomy of Facebook messages in business-to-consumer communications: what really works? Tourism and Hospitality Research, V. 16 No. 4, pp. 311-328.

[34] Kwok, L., Xie, K., \& Tori, R. (2017). Thematic framework of online review research: A systematic analysis of contemporary literature on seven major hospitality and tourism journals. International Journal of Contemporary Hospitality Management, 29(1).

[35] Kwok, L., Zhang, F., Huang, Y., Yu, B., Maharabhushanam, P. \& Rangan, K. (2015). Documenting business-to-consumer $\left(\mathrm{B}_{2} \mathrm{C}\right)$ communications on Facebook: what have changed among restaurants and consumers? Worldwide Hospitality and Tourism Themes, V. 7, 3, 283-294.

[36] Ladhari, R. \& Michaud, M. (2015). eWOM effects on hotel booking intentions, attitudes, trust, and website perceptions, International Journal of Hospitality Management, V. 46 (1), pp. 6-45.

[37] Lee, C., \& Cranage, D. (2014). Toward understanding consumer processing of negative online word-of-mouth communication: The roles of opinion consensus and organizational response strategies. Journal of Hospitality \& Tourism Research, $38,330-360$.

[38] Lee, H., Law, R. \& Murphy, J. (2011). Helpful reviewers in TripAdvisor: an online travel community, Journal of Travel \& Tourism Marketing, V. 28 No. 7, pp. 675-688.

[39] Levy, S., Duan, W. \& Boo, S. (2013). An analysis of one-star online reviews and responses in the Washington, DC, lodging market. Cornell Hospitality Quarterly 54 (1): $49-63$.

[40] Li, G., Law, R. Vu, H., Rong, J. \& Zhao, X. (2015). Identifying Emerging Hotel Preferences Using Emerging Pattern Mining technique. Tourism Management 46:311-21.

[41] Litvin, S., Goldsmith, R., \& Pan, B. (2008). Electronic word-of-mouth in hospitality and tourism management, Tourism Management, 29, 458-468.

[42] Liu, X., \& Park, S. (2015). What makes a useful online review? Implication for travel product websites. Tourism Management, V. 47, 140-151.

[43] Magno, F., Cassia, \& F. Bruni, A. (2017). Please write a (great) online review for my hotel! Guests' reactions to solicited reviews, Journal of Vacation Marketing v24 (8) pp. 1-11. 
[44] Mauri, A. \& Minazzi, R. (2013). Web reviews influence on expectations and purchasing intentions of hotel potential customers, International Journal of Hospitality Management, 34 No. 1, 99-107.

[45] Mccoll-Kennedy, J. \& B. Sparks. (2003). Application of fairness theory to service failures and service recovery. Journal of Service Research, 5, 251-266

[46] Min, H., Lim, Y., \& Magnini, V. (2015). Factors affecting customer satisfaction in responses to negative online hotel reviews the impact of empathy, paraphrasing, and speed. Cornell Hospitality Quarterly, 56, 223-231.

[47] Niu, H., \& Fan, Y. (2018). An exploratory study of online review management in hospitality services. Journal of Service Theory and Practice V. 28:1, 79-98.

[48] O'Connor, P. (2010) Managing a hotel's image on TripAdvisor. Journal of Hospitality Marketing \& Management 19: 754-772.

[49] Ogut, H. \& Tas, O. (2012). The influence of internet customer reviews on the online sales and prices in hotel industry, The Service Industries Journal, V. 32 No. 2, pp. 197214.

[50] O'Mahony, M., Smyth, B. (2009). Learning to recommend helpful hotel reviews, Proceedings of the Third ACM Conference on Recommender Systems, ACM, New York, pp. 305-308.

[51] Pantelidis, I. (2010). Electronic meal experience: a content analysis of online restaurant comments, Cornell Hospitality Quarterly, V. 51 No. 4, pp. 483-491.

[52] Park, S. \& Nicolau, J. (2015). Asymmetric effects of online consumer reviews, Annals of Tourism Research, V. 50, pp. 67-83.

[53] Park, S., \& Allen, J. (2013). Responding to online reviews problem solving and engagement in hotels. Cornell Hospitality Quarterly, V. 54 (1) pp. 64-73.

[54] Pelsmacker, P., Van Tilburg, S. \& Holthof, C. (2018). Digital marketing strategies, online reviews and hotel performance. International Journal of Hospitality Management, 72 (2018) 47-55.

[55] Phillips, P., Barnes, S., Zigan, K., \& Schegg, R. (2017). Understanding the impact of online reviews on hotel performance: An empirical analysis. Journal of Travel Research, 56 (2). 235-249.

[56] Radojevic, T., Stanisic, N., \& Stanic, N. (2015). Solo travelers assign higher ratings than families: Examining customer satisfaction by demographic group. Tourism Monogement Perspectives, 16, 247-258.

[57] Rancourt, K., (2013). Managing Your Reputation Online: Customers Expect a Response. http://www.pme36o.com/blog/managing-your-reputation-onlinecustomers-expect-a-response. 
[58] ReviewPro (2014). A basic guide to managing online reviews for hotels. Available on Internet http://www.reviewpro.com/guides/en/ReviewPro-Basic-GuidetoManaging-Online-Reviews-for-Hotels.pdf

[59] Rose, M., \& Blodgett, J. (2016). Should hotels respond to negative online reviews? Cornell Hospitality Quarterly, 1, 1-15.

[60] Sahin, I., Gulmez, M, Kitapci, \& O Olgun. (2017). E complaint tracking and online problem-solving strategies in hospitality management. Journal of Hospitality and Tourism Technology 8, 3, 372-394.

[61] Sparks, B. So, K., \& Bradley, G. (2016). Responding to negative online reviews: The effects of hotel responses on customer inferences of trust and concern. Tourism Management, 53, 74-85.

[62] Sparks, B., \& Bradley, G. (2017). A Triple A Typology of Responding To Negative Consumer-Generated Online Reviews, Journal of Hospitality \& Tourism Research, V. 41, No. 6, August 2017, 719-745

[63] Sparks, B., \& Browning, V. (2011). The impact of online reviews on hotel booking intentions and perception of trust. Tourism Management, 32(6). 1310-1323.

[64] Sparks, B., Perkins, H., \& Buckley, R. (2013). Online travel reviews as persuasive communication: The effects of content type, source, and certification logos on consumer behavior. Tourism Management, 39, 1-9.

[65] Torres, E., Adler, H. \& Behnke, C. (2014). Stars, diamonds, and other shiny things: the use of expert and consumer feedback in the hotel industry, Journal of Hospitality and Tourism Management, V. 21, pp. 34-43.

[66] Tsang, A., \& Prendergast. G. (2009). Is a 'Star' Worth a Thousand Words? The Interplay between Product-Review Texts and Rating Valences. European Journal of Marketing 43 (11/12): 1269-80.

[67] United Nations World Tourism Organization (2014). Online guest reviews and hotel classification systems, available at: http://europe.unwto.org/publication/onlineguestreviews-and-hotel-classification-systemsintegrated-approach (accessed 12 January 2018).

[68] Vermeulen, I., \& Seegers, D. (2009). Tried and tested: The impact of online hotel reviews on consumer consideration. Tourism Management, 30(1). 123-127.

[69] Viglia, G., \& Buhalis, D. (2016). The influence of e-word-of-mouth on hotel occupancy rate, International Journal of Contemporary Hospitality Management, V. 28 (9) pp. 2035-2051. 
[70] Xiang, Z., Schwartz, Z., Gerdes, J. \& Uysal, M. (2015). What can big data and text analytics tell us about hotel guest experience and satisfaction?, International Journal of Hospitality Management, V. 44, pp. 120-130.

[71] Xie K., Zhang Z., \& Zhang, Z., (2016) Effects of managerial response on consumer eWOM and hotel performance: evidence from TripAdvisor. International Journal of Contemporary Hospitality Management, V. 28 (9) pp. 2013-2034.

[72] Xie, K., Zhang, Z., \& Zhang, Z., (2014). The business value of online consumer reviews and management response to hotel performance. International Journal of Hospitality Management, 43, 1-12.

[73] You, Y., Vadakkepatt, G. \& Joshi, A. (2015). A meta-analysis of electronic word-ofmouth elasticity, Journal of Marketing, V. 29 No. 2, pp. 19-39.

[74] Zehrer, A., Crotts, J. \& Magnini, V. (2011). The perceived usefulness of blog postings: An extension of the expectancy disconfirmation paradigm. Tourism Management 32 (1) $106-13$.

[75] Zhao, X., Wang, L., Guo, X. \& Law, R. (2015). The influence of online reviews to online hotel booking intentions, International Journal of Contemporary Hospitality Management, V. 27 No. 6, pp. 1343-1346.

[76] Zhiwei, L. \& Park, B. (2015). What makes a useful online review? Implication for travel product websites, Tourism Management, 47, April, pp140-151. 